\title{
INNOVATION OF LEMBANG VOCATIONAL TRAINING CENTER TO CREATE AGRICULTURAL ENTREPRENEUR
}

\author{
Timotius Setiawan $^{1}$, Dwi Purnomo ${ }^{1}$, Ernah $^{2}$ \\ ${ }^{1}$ Faculty of Agroindustrial Technology, Padjadjaran University \\ ${ }^{2}$ Faculty of Agriculture, Padjadjaran University \\ Jl. Raya Bandung Sumedang Km. 21 Jatinangor, Sumedang - Indonesia \\ Email: timotius17002@mail.unpad.ac.id
}

\begin{abstract}
Lembang Vocational Training Center (Balai Latihan Kerja/BLK Lembang) is a government vocational training institution in charge of organizing vocational training in agriculture/agribusiness for the community, especially job seekers. The challenge faced by BLK Lembang is to create agricultural entrepreneurs expected to reduce 1.8 million unemployed in West Java (BPS, 2017). This study aims to investigate the innovations undertaken by BLK Lembang in creating agricultural entrepreneurs through agricultural vocational training. The study was conducted from November to December 2017 at BLK Lembang using qualitative descriptive method. Data were collected through secondary data, observation, in-depth interviews, and Focus Group Discussion (FGD) to several key informants. The results of this study showed that BLK Lembang has performed innovations in its vocational training system in order to create agricultural entrepreneurs that include: vision and planning, demonstration and training facilities, capacity building for instructor, training program development, training contents development, utilization of material practice, On Job Training Program, and networking. In the future, BLK Lembang will take opportunities for innovation in management and work culture, human resources, training programs, membership, facilities and partnership to improve its training system and quality in order to create more agricultural entrepreneurs.
\end{abstract}

Keywords: agricultural entrepreneur, agricultural innovation system, agricultural vocational training

\begin{abstract}
Balai Latihan Kerja (BLK) Lembang adalah lembaga pelatihan kerja pemerintah yang bertugas menyelenggarakan pelatihan kerja di bidang pertanian/agribisnis bagi masyarakat, terutama pencari kerja. Tantangan yang dihadapi oleh BLK Lembang adalah menciptakan wirausaha pertanian yang diharapkan dapat mengurangi 1,8 juta penganggur di Jawa Barat (BPS, 2017). Penelitian ini bertujuan untuk mengetahui inovasi yang dilakukan oleh BLK Lembang dalam menciptakan wirausaha pertanian melalui pelatihan kerja bidang pertanian. Penelitian dilakukan dari November hingga Desember 2017 di BLK Lembang dengan menggunakan metode deskriptif kualitatif. Data dikumpulkan melalui data sekunder, observasi, wawancara mendalam, dan Focus Group Discussion (FGD) kepada beberapa informan kunci. Hasil penelitian ini menunjukkan bahwa BLK Lembang telah melakukan inovasi dalam sistem pelatihan kerjanya untuk menciptakan wirausaha pertanian yang meliputi: visi dan perencanaan, fasilitas peraga dan pelatihan, pengembangan kapasitas untuk instruktur, pengembangan program pelatihan, pengembangan materi pelatihan, pemanfaatan bahan latihan, Program On-Job Training dan jaringan kerja sama. Di masa mendatang, BLK Lembang akan memanfaatkan peluang-peluang untuk inovasi dalam aspek manajemen dan budaya kerja, sumber daya manusia, program pelatihan, kepesertaan, fasilitas, dan jaringan kerja sama untuk meningkatkan sistem dan kualitas pelatihan dalam rangka menciptakan lebih banyak wirausaha pertanian.
\end{abstract}

Kata kunci: wirausaha pertanian, sistem inovasi pertanian, pelatihan kerja pertanian 


\section{INTRODUCTION}

Unemployment is one of problems experienced by all countries, including Indonesia. By 2016 there are 7 million unemployed people in Indonesia, and West Java being the province with the highest unemployment rate (BPS, 2017). The problem of unemployment is due to the limited number of employment and nonconformity with the job qualifications.

Entrepreneurs are believed to be able to increase productivity, create jobs, encourage economic growth, and improve the competitiveness of a country. The ratio of entrepreneurs Indonesia in 2016 reached $3.1 \%$ and is targeted to $4 \%$ in 2018. But this figure is still lower than neighboring countries, such as Singapore (7\%), Malaysia (5\%) and Thailand (4\%) (Ministry of Cooperation and Small \& Medium Enterprises, 2017). According to consensus, a country ideally has entrepreneurship as much as $5 \%$ of its total population for the country's economy to go forward (Suharti and Sirine, 2012). Therefore, increasing the number of entrepreneurs needs to be done to reduce the unemployment rate and encourage the economy of West Java (specifically) and Indonesia (in general). The same thing needs to be done in the agricultural sector. Increasing the number of agricultural entrepreneurs should be done to encourage the growth, productivity, employment, and competitiveness of the agricultural sector.

BLK Lembang is one of the few vocational training institutions that specifically and consistently organizes agricultural vocational training programs in Indonesia. Currently, BLK Lembang faced the challenge of high unemployment rate and limited jobs in the agricultural sector, where the number of companies (and the formal employment available in it) in agriculture is very limited. Therefore, BLK Lembang needs to encourage trainees to work independently as agricultural entrepreneurs. The challenge to create agricultural entrepreneurs needs to be faced with innovations in all aspects of training system. Therefore, this research intends to investigate the innovations that have been done BLK Lembang in creating entrepreneur and explore opportunities for innovation in the future.

According to the World Bank (The World Bank, 2012), innovation is a process where individuals or organizations master and apply the design and production of new goods and services to them, regardless of whether they are new to their competitors, their countries, or the world. The innovation system is a network of organizations, companies and individuals focused on bringing new products, new processes, and new organizational forms into economic use, along with institutions and policies that affect behavior and performance. The development of the agricultural sector can not be separated from agricultural education and training. Agricultural education and training play an important role in human resource capacity development that drives the agricultural sector. Agricultural education and training are also one of the agricultural innovation systems. The agricultural sector of a country will grow and have competitiveness through agricultural innovation (The World Bank, 2012).

The modern agricultural sector demands training institutions to produce highly skilled graduates. Graduates should have ability to manage agricultural cultivation, run businesses, serve the market chain, manage and improve agricultural machinery and processing, monitor quality and safety issues, and support other agricultural innovation system actors in assessing the suitability of innovation for a particular person, group, farm system, or value chain. In addition, technical graduates require important behavioral skills such as cooperation, diligence, creativity, and entrepreneurship. Reform in the management of training institutes is required for conventional training programs in order to prepare all capabilities appropriately and gender responsively. The training needs and curriculum of vocational training program should be clarified through dialogue with key sector actors (education and agriculture ministries, graduates of job training institutions, and trainers who train them for public and private sectors).

There are many definitions and insights about entrepreneurship. Havinal (2009) defines entrepreneur as someone who tries to create something new, manages production and takes risks and economic uncertainty in business. The definition is based on three perspectives on entrepreneurship: entrepreneurs as risk takers, entrepreneurs as managers (organizers), and entrepreneurs as innovators. In the context 
of agribusiness, agricultural entrepreneurs are defined as entrepreneurs who work to conduct business in the scope of broad agriculture (food crops, horticulture, plantation, animal husbandry, fisheries and forestry) ranging from upstream subsystems (such as seeds, fertilizers, pesticides providers) until downstream subsystems (such as agricultural products processing), and also support subsystem (such as machining, marketing, warehousing, financing, transportation of agriculture and its products.) (Pasaribu, 2012).

Entrepreneurs have a fundamental role in fostering economic growth. Theoretically, entrepreneurs make a new combination of production factors to produce new products and meet the demands that will change the existing market structure. The process runs in turn, results business cycles and generates economic growth. The Organization of Economic Development (OECD) also conducts national entrepreneurial activity research programs of countries annually through the Global Entrepreneurial Monitor (GEM). The result of GEM analysis shows that the level of national entrepreneur activity is related significantly to the rate of economic growth. It also shows that no country has high entrepreneurship rates with low economic growth rates. (Reynolds, et al., 2002). A case study by Mujuru (2014) in the Dotito Irrigation Scheme area of Zimbabwe shows that entrepreneurship in agriculture has been shown to increase agricultural productivity that promotes human development through participation in community life, employment, health, food availability, education, gender equality and environmental sensitivity.

\section{METHODS}

This research is a descriptive study. The research was conducted on November 2017 at the BLK Lembang. Data were collected through observation, in-depth interviews, and Focus Group Discussion (FGD). Observations and interviews are used to explore information on innovative issues that have been done by institutions, while FGDs are used to explore opportunities for institutional capacity building in the future. Respondents (key informants) selected are people who are directly involved in the innovation process and have the appropriate competencies. Respondents in this study include: Head of Institution, Subdivision
Head of Administration, Section Head of Program and Evaluation, Section Head of Organizing and Empowerment, and Coordinator of Functional Position Group.

\section{FINDINGS AND DISCUSSION Organizational and Process Review}

BLK Lembang established in 2015 The main duty is to conduct training, empowerment, and competency test of the workforce. Organizationally, BLK Lembang is categorized as Class II with structured of Head of Institution, Administration Subdivision, Program and Evaluation Section, Organizing and Empowerment Section, and Functional Position Group. The number of employees at BLK Lembang is 39 people consisting of 17 civil servants (PNS) and 22 non-civil servants. The ratio of the number of instructors, training support personnel (Heads, Subdivisions and Sections) and field support personnel (cleaning personnel, gardens, security, drivers) are (12:13:14). The staffing composition in BLK Lembang in detail can be seen in Table 1.

More than half of Lembang BLK employees are highly educated (master and bachelor graduates), mostly civil servants. While the rest are high school graduates and only one junior graduate (mostly non-civil servants). Staffing composition of BLK Lembang based on education level is presented in Table 1.

Based on age category, almost half (8 of 17) of civil servants in BLK Lembang are 50 years old or older. They consist of structural officials and instructors (special functional). While the employee with young age (under 40 years) only 5 people consisting of structural, instructors and general functional officials (see Table 3).

Table 1.

Staffing Composition in BLK Lembang by Age and Field Category

\begin{tabular}{|c|c|c|c|c|}
\hline $\begin{array}{l}\text { Position } \\
\text { Group }\end{array}$ & Major & Status & $\begin{array}{l}\text { Jumla } \\
\text { h } \\
\text { (orang } \\
\text { ) }\end{array}$ & $\begin{array}{l}\text { Jumla } \\
\text { h } \\
\text { (orang } \\
\text { ) }\end{array}$ \\
\hline \multirow{5}{*}{$\begin{array}{l}\text { Instructo } \\
\mathrm{r}\end{array}$} & Horticulture & PNS & 3 & \multirow{5}{*}{12} \\
\hline & Fishery & PNS & 2 & \\
\hline & Husbandry & PNS & 1 & \\
\hline & Processing of & PNS & 3 & \\
\hline & $\begin{array}{l}\text { Agricultural } \\
\text { Products }\end{array}$ & & & \\
\hline
\end{tabular}




\begin{tabular}{|c|c|c|c|c|}
\hline & $\begin{array}{l}\text { Agricultural } \\
\text { Mechanizatio } \\
\mathrm{n}\end{array}$ & PNS & 3 & \\
\hline \multirow{10}{*}{$\begin{array}{l}\text { Training } \\
\text { Support } \\
\text { Personel }\end{array}$} & $\begin{array}{l}\text { Head of } \\
\text { Institution }\end{array}$ & PNS & 1 & \multirow{10}{*}{13} \\
\hline & $\begin{array}{l}\text { Administratio } \\
\mathrm{n} \text { Subdivision }\end{array}$ & $\begin{array}{l}\text { PNS } \\
\text { NonPN } \\
\text { S }\end{array}$ & $\begin{array}{l}2 \\
2\end{array}$ & \\
\hline & Section of & PNS & 1 & \\
\hline & Program and & NonPN & 3 & \\
\hline & Evaluation & S & & \\
\hline & Section of & PNS & 1 & \\
\hline & Delivering & NonPN & 3 & \\
\hline & & S & & \\
\hline & Empowermen & & & \\
\hline & $\mathrm{t}^{\mathrm{t}}$ & & & \\
\hline \multirow{7}{*}{$\begin{array}{l}\text { Field } \\
\text { Support } \\
\text { Personel }\end{array}$} & Cleaning & NonPN & 3 & \multirow{7}{*}{14} \\
\hline & Services & S & & \\
\hline & Gardeners & NonPN & 4 & \\
\hline & Security & $\begin{array}{l}S \\
\text { NonPN }\end{array}$ & 6 & \\
\hline & & $\mathrm{S}$ & & \\
\hline & Driver & NonPN & 1 & \\
\hline & & $\mathrm{S}$ & & \\
\hline \multirow{2}{*}{\multicolumn{2}{|c|}{ Total Number }} & PNS & 17 & \multirow[b]{2}{*}{39} \\
\hline & & $\begin{array}{l}\text { NonPN } \\
\text { S }\end{array}$ & 22 & \\
\hline
\end{tabular}

Source: BLK Lembang, data per December 2017

Table 2.

Staffing Composition in BLK Lembang by Education Level

\begin{tabular}{|c|c|c|c|c|c|c|}
\hline Group & & $\begin{array}{l}\text { imb } \\
\text { erso } \\
\text { el o } \\
\text { S1 } \\
\end{array}$ & $\begin{array}{l}\text { er of } \\
\text { ns) wi } \\
\text { f } \\
\text { DIII }\end{array}$ & $\begin{array}{l}\text { Persone } \\
\text { ith educ } \\
\text { SLTA } \\
\end{array}$ & $\begin{array}{l}\text { el } \\
\text { cation } \\
\text { SLTP }\end{array}$ & $\begin{array}{l}\text { Total } \\
\text { (persons) }\end{array}$ \\
\hline $\begin{array}{l}\text { Head of } \\
\text { Institution }\end{array}$ & - & 1 & - & - & - & 1 \\
\hline Instructor & 3 & 7 & 2 & - & - & 12 \\
\hline $\begin{array}{l}\text { Training } \\
\text { Support } \\
\text { Personel } \\
\text { (PNS) } \\
\text { Training }\end{array}$ & 2 & 2 & - & 1 & - & 5 \\
\hline $\begin{array}{l}\text { Support } \\
\text { Personel } \\
\text { (Non-PNS) } \\
\text { Field }\end{array}$ & - & 4 & 1 & 2 & - & 7 \\
\hline $\begin{array}{l}\text { Support } \\
\text { Personel } \\
\text { (NonPNS) } \\
\end{array}$ & - & 1 & - & 12 & 1 & 14 \\
\hline $\begin{array}{l}\text { Total } \\
\text { Number }\end{array}$ & 5 & 15 & 3 & 15 & 1 & 39 \\
\hline
\end{tabular}

(Source: BLK Lembang, data per December 2017)

Table 3.

Composition of Civil Servants in BLK Lembang by Age Group

\begin{tabular}{|c|c|c|c|c|}
\hline $\begin{array}{l}\text { Age } \\
\text { Range }\end{array}$ & $\begin{array}{l}\text { Instructor } \\
\text { (persons) }\end{array}$ & $\begin{array}{l}\text { Structural } \\
\text { Position } \\
\text { (persons) }\end{array}$ & $\begin{array}{l}\text { General } \\
\text { Functional } \\
\text { Position } \\
\text { (persons) }\end{array}$ & $\begin{array}{l}\text { Total } \\
\text { (persons) }\end{array}$ \\
\hline$<35$ & 2 & - & - & 2 \\
\hline 35-39 & 1 & 1 & 1 & 3 \\
\hline $40-49$ & 2 & 2 & - & 4 \\
\hline $50-55$ & 3 & 1 & - & 4 \\
\hline$>55$ & 4 & - & - & 4 \\
\hline $\begin{array}{l}\text { Total } \\
\text { Number }\end{array}$ & 12 & 4 & 1 & 17 \\
\hline
\end{tabular}

(Source: BLK Lembang, data per December 2017)

In the managerial aspect, every process of activity always starts with planning involving all employees, coordination during implementation, and evaluation at the end of the activity. It makes BLK Lembang able to make improvements from time to time. One of the most prominent working attitudes is the high sense of responsibility and the willingness to learn new things. This began since the establishment of the BLK Lembang in 2015 in which many employees are placed not in accordance with the previous field of work. It makes BLK Lembang shows a lot of achievement even though only 2 years standing. The work culture formed in BLK Lembang is kinship and openness, where the distance between the subordinates and the top is not too visible, the ease to convey complaints, suggestions, criticism, and willingness to accept opinions.

The main duty of BLK Lembang is to provide vocational training services for society, especially job seekers in West Java Province. There are three training models held at BLK Lembang, ie: (1) 'Tailor Made' Training: training prepared on request and cooperation with companies or industries; (2) Competence Based Training: training with a more specific and measurable approach; giving more practical than theoritical activities; (3) Mobile Training Unit: non-institutional training undertaken outside BLK Lembang by using facilities already prepared in the mobile training unit's car in reaching the rural, remote, and border areas development.

The process of training in BLK Lembang is described as below:

a. Training Need Analysis (TNA)

Training Needs Analysis is conducted to find out the training needs in the regions so that the training programs are organized in accordance with the needs of the 
community. The suitability of the training program will support the graduates/employmental placement. The result of Training Needs Analysis will determine training program to be held.

b. Training Program Development The training program is a description of a training to be held. The training program contains training program title, objectives, scope, subject, level, competencies to be achieved, which is complemented with curriculum (list of competency units), syllabus (training material description) and facilities list (tools and materials).

c. Training Program Marketing Training programs that have been formulated and endorsed are then informed to the public to recruit potential trainees.

d. Recruitment and Selection of Prospective Applicants

Prospective applicants (trainee candidates) who apply then be selected according to requirements. Job seekers are given top priority to be eligible to be trainees.

e. Training Delivery

The training was carried out with a duration of 160 training hours (equivalent to 20 training days). Each training is taught by instructors who are specialized in particular major. Training materials consist of skill material (110 training hours), soft skills (40 training hours), and entrepreneurial motivation (10 training hours) by presenting practitioners/entrepreneurs from outside the BLK.

f. On Job Training (OJT)

On Job Training (OJT) is a continuation of training. Trainees are placed in related companies to apply the competencies that have been obtained and adapt to the company's work system. The purpose is to prepare trainees to enter the world of work. OJT is held for 1 month.

\section{Innovations in Creating Agricutural Entrepreneurs}

The research result shows some innovation in BLK Lembang in creating agricultural entrepreneurs as follows:

a. Vision and Planning Oriented to Entrepreneur Creation
BLK Lembang has a vision of "Becoming a professional and qualified training institute to create competent workforce and independent entrepreneurship in agribusiness". In the vision, there appears orientation to create agricultural entrepreneurs ('self-employed entrepreneurs in agribusiness'). The establishment of vision oriented to the creation of agricultural entrepreneurs shows an innovative direction and objective, in which today the most emerging paradigm in society is to work as an employee. BLK Lembang also has a development plan for the first five years in which the development which is to provide technological agricultural training facilities. The development plan is done in an effort to prepare trainees with competencies, competitiveness, and at the same time to form the image of modern agriculture.

b. Innovative Facilities Development Development of BLK Lembang is directed to form organization into a modern and advanced vocational training center in agriculture. This development is realized in the development of innovative facilities. Some of the innovative facilities can be seen in Table 4 and Figure 1. These facilities are build to support the process of competencies development of trainees become competitive agricultural entrepreneur.

c. Capacity Building Programs

BLK Lembang has held several capacity building activities by innovative trainings for instructors, such as: Training of Nutrition Mixing for Hydroponics, Training of Quail Raising, Training for Assesor, and Soft Skill Training. These programs are innovative, independent (initiated and organized by employees or organization), updated (according to society and market trend), practical (can be directly applied in training), and delivered by practitioners or experts. By these programs, BLK Lembang could provide appropriate trainings in order to create agricultural entrepreneurs. 
Table 4.

Innovative Training Facilities at BLK Lembang

\begin{tabular}{|c|c|c|}
\hline Facilities & $\begin{array}{l}\text { Function/ } \\
\text { Purpose }\end{array}$ & Innovative Properties \\
\hline $\begin{array}{l}\text { Horticulture } \\
\text { Demonstration Plot }\end{array}$ & $\begin{array}{l}\text { Demonstration, } \\
\text { garden/aesthetic, income }\end{array}$ & $\begin{array}{l}\text { Multifunction, layout, irrigation } \\
\text { system, types of plant }\end{array}$ \\
\hline Multifunctional Pond & $\begin{array}{l}\text { Rainwater harvesting, } \\
\text { aquaculture, irrigation, } \\
\text { garden/aesthetic }\end{array}$ & $\begin{array}{l}\text { Multifunction, design, sedimental } \\
\text { pond }\end{array}$ \\
\hline Hydroponic Greenhouse & Demonstration & $\begin{array}{l}\text { Hydroponic technology, } \\
\text { autofertigation, information } \\
\text { technology }\end{array}$ \\
\hline Aquaculture Pond & $\begin{array}{l}\text { Demonstration (breeding, } \\
\text { growing, aquaponic) }\end{array}$ & $\begin{array}{l}\text { Serial layout, aquaponic technology, } \\
\text { organic feed }\end{array}$ \\
\hline $\begin{array}{l}\text { Boiler and Sterilsator for } \\
\text { Mushroom Media }\end{array}$ & Demonstration & Modified equipment \\
\hline $\begin{array}{l}\text { Marketing } \\
\text { System/Mechanism for } \\
\text { Agricultural Product } \\
\end{array}$ & Selling agricultural products & Auction method \\
\hline Water supply & $\begin{array}{l}\text { Providing water for domestic } \\
\text { and agricultural activities in } \\
\text { BLK Lembang }\end{array}$ & $\begin{array}{l}\text { Mountain water source, channel } \\
\text { building }\end{array}$ \\
\hline
\end{tabular}
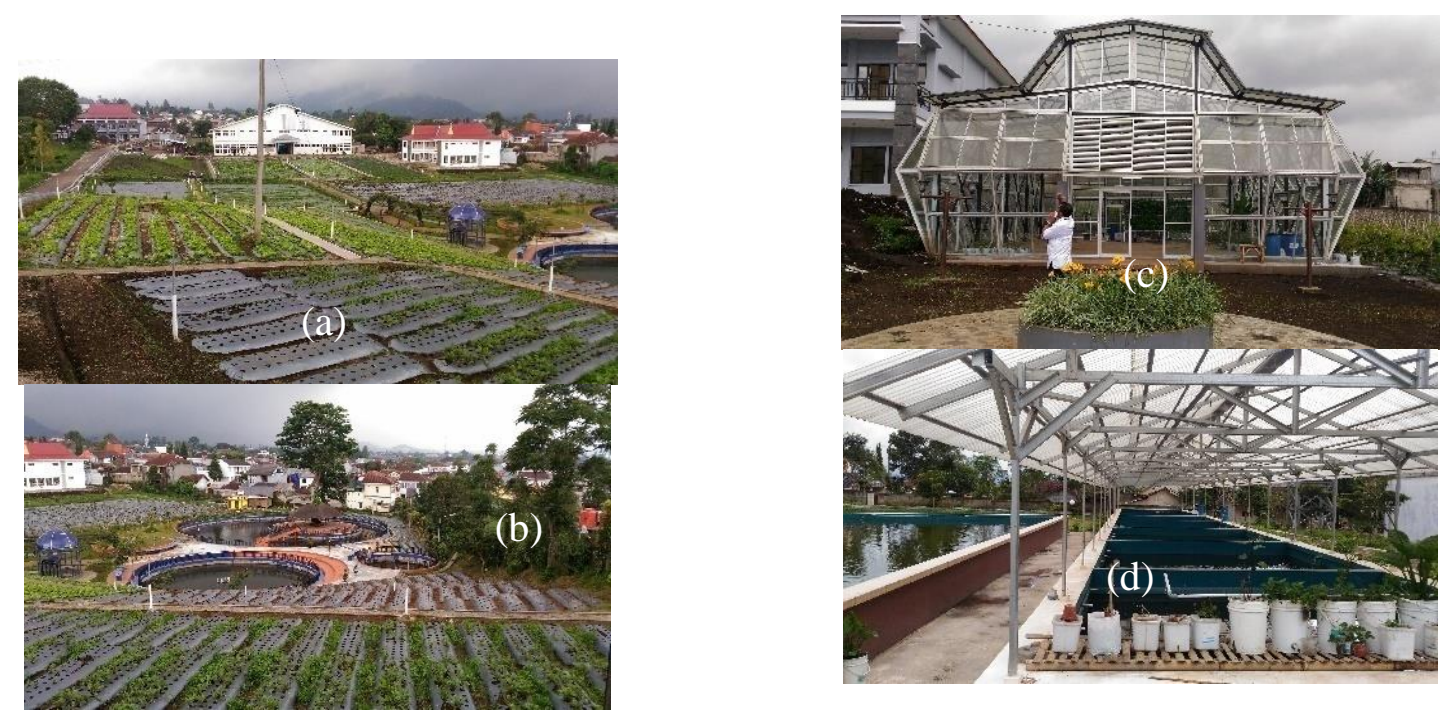

Figure 1.

Some Training Facilities in BLK Lembang: (a) Horticulture Demonstration Plot, (b)

Multifunctional Pond, (c) Hydroponic Greenhouse, and (d) Aquaculture Pond (Source: research documentation)

d. Development of Innovative Training Program Since 2016, BLK Lembang has developed new training programs, such as Gardening/Landscape Training Program. 
The development of training programs is a key element in creating agricultural entrepreneurs because through appropriate training programs trainees will be able to start and develop the right business. One approach used in the development of training program is Training Need Analysis (TNA) based on existing business opportunities.

e. Strengthening Entrepreneurship Aspect in Training Material Content

Mental, character and attitude become important thing that form agricultural entrepreneurship. BLK Lembang realized that and developed training content that consist of 110 training hours of technical skill, 40 training hours of soft skill and 10 training hours of motivation (total duration 160 training hours). Technical skill material contains competencies related to the business field; soft skill material contains mental building and strengthening, entrepreneurial character and attitudes; motivation material contains success story by practitioners or entrepreneurs. The program is continued by two weeks On Job Training to strengthen and prepare the trainees before entering work field or business.

f. Utilization of Practical Materials to Encourage Entrepreneurship Practical materials are consumables used for practical activities in training. Trainees often produce products in training. BLK Lembang utilizes those products by giving it to trainees in starting business up. Utilization of materials or products is intended as a trigger for trainees to start a business and develop it until they become independent. Some considerations in the use of materials or products of training are accountability and group dynamics. Therefore, the utilization of the materials and products should be monitored by BLK Lembang to be more effective.

g. On Job Training

On Job Training (OJT) is a training program implemented in the workplace. Conventional paradigm looks and places OJT program as a post training process in order to adapt trainees with work environment. In the context of entrepreneurship training, OJT can be implemented in the form of business incubators in which trainees are prepared to become entrepreneurial candidates in order to run their business independently.

h. Establishment of Stakeholder

Communication Forum

BLK Lembang recognizes the need of partnership with other parties to create agricultural entrepreneurs. Therefore, BLK Lembang invited relevant stakeholder to join in Communication Forum and cooperate to create agricultural entrepreneurs in accordance with their roles and functions. BLK Lembang has invited various parties to involve in Training Need Analysis (TNA), marketing training programs, recruitment of trainee candidates, training implementation, OJT, mentoring for graduated trainees, and in terms of work placement. Those are: Local Governments (Desa and Kecamatan), agroindustries, Ministry of Rural, Underdevelop Region Development, and Transmigration (Kemendesa), higher education institutions, Lembang Agriculture Training Center (BPPP), Industrial and Trading Agency of West Java Province, "Trubus" (Publisher), and HM Sampoerna Group Company.

\section{Opportunities for Innovation in Future}

Innovation should be a continues process for facing never-ending change. Therefore, BLK Lembang needs to explore the opportunities for innovation in the future. Based on the results of the Focus Group Discussion (FGD) with several key informants, there are several aspects and opportunities for innovation in BLK Lembang for coming years in order to create agricultural entrepreneurs.

a. Management and Work Culture

BLK Lembang recognizes the need to strenghten management and productive work culture. Therefore, BLK Lembang plans to implement Quality Management Certification Program and the 'Five-S' Program (work culture program adopted from Japan) in the next year. The both programs will be driven to improve the quality of training in order to encourage the creation of agricultural entrepreneurs.

b. Human Resources Instructor quality and capacity are an important factor and become spearhead in 
agribusiness training to create agricultural entrepreneurs. Therefore, quality and capacity building program for instructor will be still implemented in the future with considering innovation, novelty, independency, expertise, and aplicability.

c. Training Programs BLK Lembang will continue to develop innovative training programs in the future. Some training programs planned to be developed are as follows: Agricultural Engineering Training Program, Tissue Culture Training Program, Agricultural Education Program for Children, Agricultural Training Program for Public, Competency Test Program, "Workplace" Program (as business incubator for trainees) and Evaluation and Development for Alumni.

d. Trainee Recruitment

BLK Lembang plans to improve the recruitment process of trainees by measuring the interest trainee candidate. Currently, measurement instruments have been developed and will be implemented in the next year recruitmen. BLK Lembang also requires a Statement of Support from Local Goverment Institutions (Pemerintah Desa dan Kecamatan) and Local Government's Business Unit (Badan Usaha Milik Desa/BUMDes) for trainee or area candidate to ensure trainee will receive support from local government after training. The support could be funding, investment, marketing and/or coaching.

e. Facilities

Facilities are important element in training process in order to create agricultural entrepreneurs. BLK Lembang plans to develop facilities for Agricultural Engineering Training Program which will held next year. Also, BLK Lembang plans to build the "Rumah Jamur Kekinian" Facility, a building designed creatively, attractively, comfortably and aesthetically to cultivate and show oyster mushroom cultivation for public and trainee. This facility is expected to attract both trainees and visitors and support the marketing of Lembang BLK training program

f. Partnership BLK Lembang will continue the partnership with stakeholders in future because its impact and effectiveness to create the agricultural entrepreneurs. Therefore, BLK Lembang plans to hold a Stakeholder Communication Forum (which has been initiated in 2017) three times a year while continuing collaboration with government, private, education institution and also entrepreneurs to join and contribute to the creating of agricultural entrepreneurs.

\section{CONCLUSIONS}

BLK Lembang as a vocational training institution in agriculture has made various innovations to create agricultural entrepreneurs through agribusiness training proces. The innovations include vision and planning, facilities, human resources (instructors) quality and capacity development program, training programs development, training instruments, utilization of practical materials to encourage entrepreneurship, On Job Training program, and establish communication forum with stakeholders. In the future, BLK Lembang plans to continue innovations in management and work culture, human resource development, training programs development, trainee recruitment, facilities and partnership. Through the innovations, BLK Lembang would show its role and progress in creating independent and professional agricultural workforces from year to year.

\section{ACKNOWLEDGEMENTS}

The authors thank to the Head of Lembang Vocational Training Center (BLK Lembang) and all employees who have opened up and supported this research.

\section{REFERENCES}

BPS. 2017. Statistical Year Book of Indonesia 2017. Jakarta: Badan Pusat Statistik.

Havinal \& Veerabhadrappa. (2009). Management and Entrepreneurship.

New Age International Publisher.

Ministry of Cooperation and Small \& Medium Enterprises. (2017). Jurus Jitu

Reformasi Birokrasi. Buletin

Cooperative No. 1 - Maret 2017.

Mujuru, Joice, T.R. (2014). Entrepreneurial Agriculture for Human Development: A Case Study of Dotito Irrigation Scheme, Mt. Darwin. International Journal of 
Humanities and Social Science Vol. 4 No. 4, February 2014

Pasaribu, A. M. (2012). Kewirausahaan

Berbasis Agribisnis. Yogyakarta:

Penerbit Andi.

Reynolds, P. D., Bygrave W.D., Autio, E.,

Cox, L.W., \& Hay, M. (2002). Global

Entrepreneurship Monitor 2002

Executive Report. Wellesley,

MA/London: Babson College/London

Business School.

Suharti, L., \& Sirine, H. (2011). Faktor-faktor yang Berpengaruh Terhadap Niat Kewirausahaan (Entrepreneurial Intention) (Studi Terhadap Mahasiswa Universitas Kristen Satya Wacana, Salatiga). Jurnal Manajemen dan Kewirausahaan, Vol.13, No.2, September 2011: 124-134.

The World Bank. (2012). Agricultural Innovation System: An Investment Book. Washington DC: The World Bank. 
Vol. 3, No. 1, Juli 2018: 359-426

AGRICORE:Jurnal Agribisnis dan Sosial Ekonomi Pertanian 